\title{
EFEKTIVITAS PENYELESAIAN SENGKETA PERBANKAN SYARIAH MELALUI MEKANISME FASILITASI OLEH OTORITAS JASA KEUANGAN (OJK) ${ }^{1}$
}

\author{
Dewi Nurul Musjtari*, Ani Yunita, Khaeruddin Hamsin \\ Fakultas Hukum Universitas Muhammadiyah Yogyakarta \\ Jalan Brawijaya, Kasihan, Bantul, Yogyakarta \\ dewinurulmusjtari@umy.ac.id
}

\begin{abstract}
OJK has practiced a model of dispute settlement with facilitation. The purpose of this study was to determine the effectiveness of sharia banking dispute settlement through OJK and the implementation of the dispute settlement model applied. This research is a normative and empirical legal research that uses qualitative analysis. The Financial Services Authority (OJK) in practice has effectively applied the model of dispute resolution with facilitating techniques by clarifying to the parties, with the achievement of all complaints received by OJK through the education and consumer protection sections in OJK DIY and Central Java can be completed in accordance with the period, namely 20 (twenty) working days with an extension of up to 30 (thirty) working days with a $100 \%$ success rate.
\end{abstract}

Keywords: Effectiveness; Dispute Settlement; Islamic Banking; Financial Services Authority $(O J K)$

\begin{abstract}
Abstrak
OJK telah mempraktikkan model penyelesaian sengketa dengan fasilitasi. Tujuan penelitian ini adalah untuk mengetahui efektifitas penyelesaian sengketa perbankan syariah melalui OJK dan implementasi model penyelesaian sengketa yang diterapkan. Penelitian ini merupakan penelitian hukum normatif dan empiris yang menggunakan analisis kualitatif dengan paradigma konstruktif. Otoritas Jasa Keuangan (OJK) dalam praktiknya telah efektif menerapkan model penyelesaian sengketa yang dikenal dengan teknik fasilitasi, dengan melakukan klarifikasi kepada para pihak, dengan capaian seluruh pengaduan yang diterima OJK melalui bagian edukasi dan perlindungan konsumen di OJK DIY maupun Jawa Tengah dapat diselesaikan sesuai dengan jangka waktu yaitu 20 (dua puluh) hari kerja dengan perpanjangan hingga 30 (tiga) puluh hari kerja dengan tingkat keberhasilan $100 \%$.
\end{abstract}

Kata Kunci: Efektivitas; Penyelesaian Sengketa; Perbankan Syariah; Otoritas Jasa Keuangan $(\mathrm{OJK})$

\footnotetext{
1 Hasil penelitian ini didanai oleh Lembaga Penelitian, Publikasi dan Pengabdian Masyarakat Universitas Muhammadiyah Yogyakarta pada tahun pelaksanaan 2018. Penelitian dilaksanakan dalam rangka kompetisi Penelitian Unggulan Prodi (PUP).
} 


\section{A. Pendahuluan}

Penyelesaian sengketa secara nonlitigasi yang memiliki banyak manfaat, keuntungan dan berkembang di masyarakat secara efektif adalah mediasi (Zaini, 2018). Adapun manfaat dan keuntungan menggunakan mediasi antara lain bahwa sengketa dengan menghadirkan seorang mediator, permasalahan dapat diselesaikan dengan win-win solution, waktu penyelesaian tidak berkepanjangan, biaya lebih ringan. Penyelesaian sengketa dengan mediasi akan tetap menjaga hubungan antara dua orang yang bersengketa dan terhindarkannya persoalan mereka dari publikasi yang berlebihan. Salah satu penyelesaian sengketa secara mediasi yang berkembang sangat pesat adalah penyelesaian sengketa melalui Otoritas Jasa Keuangan (OJK).

Pemahaman masyarakat tentang mediasi melalui OJK belum optimal, selama ini masyarakat memahami mediasi adalah penyelesaian sengketa dengan mempertemukan kedua belah pihak yang dilakukan oleh mediator. Faktanya terdapat model lain yang diterapkan di OJK dalam penyelesaian sengketa perbankan syariah. Adapun model yang dimaksud dan diketahui efektif berhasil menyelesaikan sengketa perbankan syariah melalui OJK adalah model fasilitasi.

Keberadaan model fasilitasi ini mulai diterapkan sejak adanya Peraturan Otoritas Jasa Keuangan No. 01/POJK.07/2013 (selanjutnya ditulis POJK No. 1 Tahun 2013). Dalam kenyataannya model fasilitasi ini belum banyak diketahui oleh para pihak yang bersengketa maupun masyarakat. Model fasilitasi jika diterapkan dalam penyelesaian sengketa perbankan syariah dengan efektif tentu sangat menguntungkan bagi para pihak yang bersengketa terutama dalam penyelesaian sengketa perbankan syariah. Dengan terwujudnya hal tersebut maka OJK secara tidak langsung juga membantu dalam membangun sistem hukum yang kondusif serta mendukung industri keuangan syariah sehingga dapat memberikan perlindungan hukum bagi para pihak yang bersengketa untuk mewujudkan perdamaian.

Fasilitasi yang telah dilakukan oleh OJK telah berjalan dengan baik, namun dalam pelaksanaannya masih memerlukan evaluasi. Dalam kenyataannya, penyelesaian sengketa perbankan syariah di OJK berdasarkan perspektif sebagian konsumen dinilai belum efektif. Oleh karena itu perlu digali alasan-alasan belum efektifnya penyelesaian sengketa perbankan syariah melalui OJK. Berdasarkan alasan tersebut perlu ditemukan cara-cara agar penyelesaian sengketa perbankan syariah melalui OJK agar dapat berjalan secara efektif dan memenuhi harapan masyarakat. Terkait dengan model Fasilitasi yang diterapkan di OJK perlu diketahui pula dasar hukum, alasan dan bagaimana penerapan model Fasilitasi dalam penyelesaian sengketa perbankan syariah.

Untuk menguraikan tentang pengertian penyelesaian sengketa, Salim H.S. dan Nurbani memberikan definisi "teori penyelesaian sengketa merupakan teori yang mengkaji dan menganalisis tentang kategori atau penggolongan sengketa atau pertentangan yang timbul dalam masyarakat, faktor penyebab terjadinya sengketa dan cara-cara atau strategi yang digunakan untuk mengakhiri sengketa tersebut'(Salim, 2013).

Adapun ruang lingkup teori penyelesaian sengketa, meliputi: jenis-jenis sengketa, faktor-faktor penyebab timbulnya sengketa dan strategi di dalam penyelesaian sengketa (Salim, 2013) . Selain teori penyelesaian sengketa, dasar yang digunakan oleh OJK dalam menjalankan tugasnya didasarkan pula pada teori kewenangan. Menurut Salim H.S. dan Nurbaini, "Teori kewenangan (authority theory) merupakan teori yang mengkaji dan menganalisis tentang kekuasaan dari organ pemerintah untuk melakukan kewenangannya, baik dalam lapangan hukum publik maupun hukum privat". Adapun "unsur-unsur yang tercantum dalam teori kewenangan meliputi: adanya kekuasaan, adanya organ pemerintah dan sifat hubungan hukumnya" (Salim, 2013). 
Bank syariah dalam proses penyelesaian sengketa, agar terwujud penyelesaian sengketa secara efisien, efektif, cepat, sederhana dan biaya ringan selain berpedoman pada beberapa peraturan perundangan dan sumber hukum lainnya, seharusnya juga menerapkan beberapa prinsip atau asas-asas. Adapun beberapa prinsip atau asas yang utama harus diterapkan antara lain mendasarkan pada prinsip syariah, prinsip kehati-hatian (prudential regulation). Selain itu Bank Syariah harus menjalankan fungsi sebagai agent of trust.

Prinsip Syariah didasarkan pada Pasal 1 angka 12 Undang-undang Nomor 21 Tahun 2008 tentang Perbankan Syariah yang menyebutkan: Prinsip Syariah adalah prinsip Hukum Islam dalam kegiatan perbankan berdasarkan fatwa yang dikeluarkan oleh lembaga yang memiliki kewenangan dalam penetapan fatwa di bidang syariah. Pengertian lain tentang Prinsip Syariah diuraikan oleh Gemala Dewi, yang menyebutkan bahwa "Prinsip syariah adalah aturan perjanjian berdasarkan Hukum Islam antara bank dan pihak lain untuk menyimpan dana/atau pembiayaan kegiatan usaha, atau kegiatan lainnya yang dinyatakan sesuai dengan syariah, antara lain pembiayaan berdasarkan bagi hasil (mudharabah),..." (Dewi, 2006).

Dalam penerapan prinsip kehati-hatian ini bank seharusnya memperhatikan dan menerapkannya. Sutan Remy Syahdeini menyebutkan bahwa rambu-rambu kesehatan bank atau prudential standards sebagaimana diuraikan di bawah ini harus mendapat perhatian yang cermat dari setiap bank, baik bank yang semata-mata melakukan kegiatan berdasarkan prinsip syariah (bank syariah) saja maupun bank konvensional yang memiliki islamic window (memiliki cabang-cabang khusus syariah). Pelanggaran terhadap rambu-rambu tersebut diancam sanksi, bukan saja berupa sanksi administratif yang dapat dijatuhkan oleh Bank Indonesia terhadap banknya maupun terhadap pengurus dan pemiliknya, amun juga diancam sanksi pidana penjara dan denda serta sanksi perdata bagi pengurus bank syariah yang bersangkutan (Syahdeini, 1999).

Penerapan prinsip kehati-hatian ini juga harus memperhatikan asas itikad baik yang obyektif yang berarti patud dan adil. Ridwan Khairandy berpendapat bahwa aturan-aturan yang dimuat dalam kontrak itu dirumuskan oleh pribadi-pribadi yang bebas dan rasional, maka aturan itu tidak hanya bersifat rasional, tetapi juga harus patut. Teori keadilan oleh John Rawls, memusatkan perhatiannya pada bagaimana mendistribusikan hak dan kewajiban secara berimbang dalam masyarakat, sehingga setiap orang berpeluang memperoleh manfaat darinya dan secara nyata menanggung beban yang sama. Demi menjamin distribusi yang patut serta mendorong kerjasama sosial, maka menjadi penting bahwa prinsip yang pertama-tama keadilan yang berfungsi sebagai panduannya haruslah merupakan kesepakatan yang patut (Khairandy, 2004).

Dalam penyelesaian sengketa di perbankan syariah selain harus memperhatikan prinsip syariah dan prinsip kehati-hatian sebagaimana telah diuraikan di atas maka perbankan syariah harus menjalankan fungsi sebagai agent of trust. Irsyad Lubis menjelaskan agent of trust adalah "aktivitas bank sebagai financial intermediary menjalankan fungsinya atas dasar kepercayaan yang diterima oleh bank dari kepercayaan masyarakat yang diberikan berupa amanat agar bank mengelola dan mengamankan dana yang disimpan masyarakat di bank tersebut. Fungsi bank sebagai Agent of Trust ini tentu tidak terlepas dari prinsip saling menguntungkan bagi kedua belah pihak"(Lubis, 2010) .

Penelitian yang dilakukan terkait dengan mediasi oleh peneliti sebelumnya adalah tentang mediasi yang dilakukan melalui peradilan agama dengan judul "The Reposition of Mediation Process in Islamic Economic Dispute Resolution Trough Religious Court After PERMA No. 1 of 2016 (Radliyah, N. and Musjtari, 2017)". Pada penelitian yang dilakukan Radliyah dan 
Musjtari fokus penelitian adalah mengetahui reposisi proses mediasi dalam penyelesaian sengketa ekonomi Islam melalui peradilan agama setelah berlakunya Peraturan Mahkamah Agung Nomor 1 Tahun 2016. Penelitian lain, dilakukan oleh Sawitri dengan judul "Mediasi Perbankan sebagai Alternatif Penyelesaian Sengketa Bank dan Nasabah Melalui Otoritas Jasa Keuangan", dengan tujuan penelitian "untuk mengetahui mediasi yang dilakukan oleh OJK dalam mengatasi sengketa antara bank dan nasabah dan hambatan-hambatan yang timbul dalam proses mediasi setelah beralihnya fungsi pengawasan dari Bank Indonesia ke OJK" (Sawitri, 2016).

Perbedaan penelitian yang dilakukan penulis dengan penelitian yang dilakukan oleh Sawitri bahwa temuan peneliti yang ditulis pada artikel ini untuk mengetahui beberapa model penyelesaian sengketa perbankan syariah melalui OJK dan mengetahui efektifitas penerapan penyelesaian sengketa perbankan syariah melalui OJK.

Belum efektifnya mediasi perbankan yang telah dilakukan selama ini, mendorong penulis melakukan penelitian dengan perumusan permasalahan bagaimanakah efektifitas penyelesaian sengketa perbankan syariah melalui OJK dan implementasi model penyelesaian sengketa yang diterapkan. Ukuran efektifitas digunakan faktor-faktor Efektifitas dalam penegakan hukum oleh Soerjono Soekanto. Urgensi penelitian ini adalah untuk mengkaji efektivitas penyelesaian sengketa perbankan syariah dan untuk pengembangan lembaga penyelesaian sengketa perbankan syariah di Indonesia. Hasil penelitian ini digunakan untuk meningkatkan kompetensi peneliti di bidang pengembangan Hukum Ekonomi Islam.

\section{B. Metode Penelitian}

Penelitian ini dilakukan dengan tradisi kualitatif (Moleong, 2011). Penelitian lapangan dilakukan di OJK Semarang dan DIY. Penelitian lapangan, dilakukan untuk mengetahui fakta sosial yang ada dalam praktik dan terjadi pada proses penyelesaian sengketa perbankan syariah di OJK Semarang dan DIY. Penelitian ini menggunakan tata aturan socio legal studies. Menurut Simarmata, "Socio Legal Studies melihat hukum sebagai salah satu faktor dalam sistem sosial yang dapat menentukan dan ditentukan"(Simarmata, 2007).

Data sekunder dalam penelitian ini, diperoleh melalui penelitian kepustakaan dan dokumen hukum, yang meliputi: 1) Bahan Hukum Primer, yang terdiri dari: a) Undang-Undang Nomor 21 Tahun 2011 dan penjelasannya, Peraturan Otoritas Jasa Keuangan No. 01/POJK.07/2013, 2) Bahan Hukum Sekunder, terdiri dari buku-buku tentang perbankan syariah, teori hukum, metodologi penelitian hukum, jurnal, proceeding. Data Primer diperoleh melalui penelitian di lapangan, yang dilakukan dengan observasi, wawancara yang meliputi:1) Law sanction institution: Staff OJK DIY dan Jawa Tengah, Mediator dan Fasilitator di OJK 2) Role Occupant: Managemen Bank Syariah dan Nasabah Bank Syariah. Teknik pengumpulan data dilakukan dengan hermeneutika, sosiologi hukum dan fenomenologi.

Data yang ditemukan pada penelitian kepustakaan maupun dari penelitian lapangan diklasifikasikan terlebih dahulu, kemudian diolah berdasarkan analisis deskriptif kualitatif. Pengertian deskriptif adalah analisis yang dilakukan dengan menggambarkan secara jelas keadaankeadaan senyatanya. Pengertian kualitatif adalah analisis terhadap data yang dinyatakan oleh responden dan nara sumber kemudian diuraikan sehingga diperoleh suatu pengertian. Berdasarkan pengertian tersebut maka yang dimaksudkan deskriptif kualitatif adalah analisis yang menggambarkan efektifitas penyelesaian sengketa perbankan syariah di OJK Semarang dan Daerah Istimewa Yogyakarta. 


\section{Hasil dan Pembahasan}

\section{Hasil Penelitian}

Untuk menemukan jawaban atas perumusan permasalahan pada penelitian ini, dilakukan penelitian lapangan dengan melakukan wawancara kepada Bapak Widiono dan Bapak Hans Ori Lewi di OJK Semarang yang dilaksanakan pada Hari Kamis, tanggal 23 Agustus 2018, Jam 14.00-16.00 WIB, dengan hasil sebagai berikut. Penyelesaian sengketa yang dilakukan oleh OJK bukan dikategorikan sebagai mediasi namun disebut dengan Fasilitasi. Fasilitasi merupakan mekanisme penyelesaian sengketa non litigasi yang merupakan bagian dari mekanisme melalui mediasi secara khusus yang didasarkan pada POJK No. 1 Th. 2013. Ruang lingkup penyelesaian sengketa melalui mekanisme fasilitasi di OJK adalah penyelesaian sengketa keperdataan yang meliputi sengketa yang terkait dengan finansial dan pelanggaran atas peraturan perundangundangan. Kekhususan mekanisme fasilitasi ini, fasilitator tidak memepertemukan para pihak dalam suatu forum. Fasilitator menerima salah satu pihak, misalnya: seorang nasabah atau pihak yang mempunyai permasalahan dengan salah satu pelaku usaha jasa keuangan (PUJK) akan menyampaikan permasalahannya kepada fasilitator di OJK. Fasilitator akan melakukan pendataan dan membuat check list atas permasalahan yang dihadapai oleh seorang nasabah atau pihak tersebut, selanjutnya fasilitator akan menyampaikan permasalahan tersebut kepada pihak PUJK untuk dikomunkasikan kepada seorang nasabah atau pihak tersebut pada forum lain. Dalam jangka waktu 20 (dua puluh hari kerja) pihak PUJK diharapkan dapat menyelesaian permasalahan dan melaporkan hasil komunikasinya dengan nasabah atau pihak dimaksud.

Penyelesaian sengketa yang telah diselesaikan di OJK Semarang, pada tahun 2015: 200 perkara, tahun 2016: 200 perkara, tahun 2017: 300 perkara dan hingga Juli 2018: 200 perkara. Berdasarkan data tersebut maka rata-rata pertahun 225 kasus. Jenis sengketa ekonomi syariah yang diselesaikan antara lain: sengketa perbankan syariah dan sengketa asuransi syariah.

Pedoman yang digunakan antara lain Undang-undang Nomor 21 Tahun 2008 tentang Perbankan Syariah, Undang-undang Nomor 21 Tahun 2011 tentang Otoritas Jasa Keuangan, POJK No. 1 Th. 2013 tentang Perlindungan Konsumen Sektor Jasa Keuangan dan POJK No. 1 Th. 2014 tentang Lembaga Alternatif Jasa Keuangan di Sektor Jasa Keuangan, Surat Edaran Otoritas Jasa Keuangan Nomor 54 SEOJK.07/2016 tentang Monitoring Lembaga Alternatif Penyelesaian Sengketa di Sektor Jasa Keuangan, Keputusan Nomor KEP-01/D.07/2016 tanggal 21 Januari 2016 tentang Daftar Lembaga Alternatif Penyelesaian Sengketa Di Sektor Jasa Keuangan. Standar Operating Prosedur (SOP) sebagai acuan dalam penyelesaian sengketa di dasarkan pada SE OJK Nomor 2/SEOJK.07/2014 tentang Pelayanan dan Penyelesaian Pengaduan Konsumen pada Pelaku Jasa Keuangan.

Proses fasilitasi seharusnya dimulai dengan Perjanjian Fasilitasi yang ditandatangani oleh Konsumen dan Pelaku Jasa Keuangan yang didasarkan Pada Pasal 44 POJK No. 1 Th. 2013. Namun dalam praktiknya, dalam hal terdapat situasi dan kondisi tertentu fasilitator tidak mempertemukan kedua belah pihak. Proses penyelesaian sengketa dilakukan dengan jangka waktu $20-30$ hari kerja. Nilai nominal yang disengketakan maksimal $\mathrm{Rp}$. 500.000.000,00 untuk sengketa perbankan dan Rp. 750.000.000,00 untuk sengketa asuransi. Tingkat keberhasilan penyelesaian sengketa $100 \%$ (persen). Contoh kasus yang diselesaikan melalui OJK: nasabah mengajukan pembiayaan ke salah satu bank syariah namun dalam praktiknya bank syariah menerapkan biaya yang lebih besar dari yang seharusnya, agen asuransi syariah tidak menyetorkan premi asuransi.

Luaran dari proses fasilitasi yang dilakukan oleh OJK adalah Akta Kesepakatan yang ditandatangani oleh 
Konsumen dan Pelaku Usaha Jasa Keuangan (PUJK). Dalam hal tidak terdapat kesepakatan maka dituangkan dalam berita acara hasil fasilitasi OJK yang ditanda tangani oleh Konsumen dan Pelaku Usaha Jasa Keuangan. Pelaksanaan atas Akta Kesepakatan yang dibuat oleh Konsumen dan PUJK dilaksanakan dengan pengawasan dari OJK. Dalam hal terdapat pelanggaran atas isi Akta Kesepakatan yang telah dibuat maka kepada PUJK dapat dikenakan sanksi yang didasarkan pada Pasal 53 POJK No. 1 Th. 2013.

Wawancara dengan Ibu Tika Asteria Diantika (Kepala Sub Bagian Edukasi dan Perlindungan Konsumen di OJK DIY yang dilaksanakan pada Hari Jum'at, 31 Agustus 2018, Jam 13.00-15.00 WIB, dengan hasil sebagai berikut. Pada prinsipnya OJK DIY menerapkan serangkaian peraturan sebagaimana yang dilakukan oleh OJK Semarang. Pengaduan nasabah yang diterima di OJK DIY pada tahun 2017 sebanyak 200 pengaduan tertulis dan 500 pengaduan secara lisan. Pada tahun 2018 per tanggal 28 Agustus 2018 sebanyak 167 pengajuan tertulis dan 320 pengaduan langsung. Pengaduan terkait Sistem Layanan Informasi Keuangan (SLIK) sebanyak 1250 pengaduan. Tingkat keberhasilan penyelesaian $100 \%$. Ibu Tika melengkapi keterangan dengan menjelaskan tahapan penyelesaian sengketa perbankan sebagai berikut: (a) Penyelesaian sengketa melalui Internal Dispute Resolution (IDR) di PUJK; (b) Penyelesaian sengketa melalui OJK; (c) Penyelesaian sengketa melalui Lembaga Alternatif Penyelesaian Sengketa (LAPS); (d) Penyelesaian sengketa melalui jalur non litigasi ke lembaga arbitrase atau pengadilan sesuai dengan perjanjian (akad) yang dibuat oleh para pihak.

Contoh kasus yang diselesaikan melaui OJK antara lain wanprestasi yang dilakukan PUJK, pendebetan kartu ATM tanpa sepengetahuan nasabah, layanan yang tidak lancar. Dalam hal IDR tidak berhasil maka penyelesaian sengketa dapat dilakukan di OJK dengan model fasilitasi dengan tahapan: (a) Ada bukti IDR dari nasabah; (b)
OJK memanggil pihak lembaga jasa keuangan terlapor untuk dilakukan klarifikasi terkait pengaduan dari nasabah. Pada tahapan ini ada risalah pertemuan; (c) Bank Syariah menceritakan peristiwa yang terjadi dan membawa bukti terkait pelaporan; (d) Bank Syariah memanggil nasabah, kemudian menjelaskan peristiwa yang dialami nasabah, membuat risalah dan dilanjutkan menyampaikan laporan perkembangan penyelesaian kasus ke OJK; (e) Waktu penyelesaian kasus 20 (dua puluh) hari kerja; (f) Bank berkirim surat ke OJK terkait penjelasan dan komunikasi yang dilakukan Bank Syariah dengan nasabah; (g) OJK menyampaikan perkembangan penyelesaian kasus kepada nasabah; (h) Kasus selesai (Case Close).

\section{Efektifitas Penyelesaian Sengketa Perbankan Syariah melalui Mekanisme Fasilitasi oleh OJK}

Penyelesaian sengketa perbankan syariah didasarkan pada akad syariah. Eksistensi akad syariah adalah adanya hubungan hukum antara bank syariah dan nasabah. Dalam pengelolaan bank syariah yang menjalankan fungsi intermediary antara penghimpunan dan pembiayaan maka timbul hubungan hukum. Pada tahapan pembiayaan, hubungan hukum antara bank syariah dan nasabah didasarkan pada Akad Pembiayaan. Penggunaan Akad Pembiayaan dilakukan berdasarkan kepatuhan yang didasarkan pada Hukum Islam dan Fiqh Muamalah. Hal ini sesuai dengan pendapat Ahmad Ibrahim yang menyebutkan: "Banking and Financial operation undertaken by Muslims will have to be conducted in compliance with the shariah laws and the Fiqh al-Muamalah. The modern banking and financial system has come into being to meet the human needs for financing from the capital belonging to others, other than one's self and these take the form of either equity financing or debt financing" (Ibrahim, 1997).

Bank Syariah dikenal dengan nama lain yaitu bank tanpa bunga (la riba bank), Bank Islam (Islamic Bank), dan Bank Nirbunga. 
Perbankan Syariah mulai diprakarsai sejak tahun 1990-an. Bank syariah yang pertama kali berdiri di Indonesia dan murni syariah adalah Bank Muamalat Indonesia. Hubungan hukum antara bank dan nasabah merupakan bagian dari kegiatan muamalah. Di dalam hukum Islam muamalah dalam arti luas adalah aturan-aturan (hukum) Allah untuk mengatur manusia dalam kaitannya dengan urusan duniawi dalam pergaulan sosial (Suhendi, 2002). Setiap orang dapat melakukan muamalah seperti dalam hubugan hukum antara parktisi di bank syariah, nasabah dan notaris (Maulin, M. dan Mulyaningsih, 2014) .

Dalam praktik operasionalisasi bank syariah, agar tidak menyimpang dari tuntunan syariah, maka pada setiap bank syariah diangkat manager dan pimpinan bank yang menguasai prinsip muamalah Islam. Disampin itu juga dibentuk Dewan Pengawas Syariah (DPS) yang bertugas mengawasi operasional bank dari aspek kesyariahannya. Dasar hukum yang utama dalam mengoperasionalkan bank syariah adalah Al Qur'an dan Hadits. Berikut ini akan dinukilkan beberapa ayat-ayat dalam Al-Qur'an, antara lain: Al-Baqarah: 275, AlImran: 130, dan An-Nisa': 29.

Selain beberapa ayat Qur'an di atas maka berdasarkan hukum positif, landasan dalam mengopersionalkan Bank Syariah adalah Undang-undang Nomor 21 Tahun 2008 tentang Perbankan Syariah (UU Perbankan Syariah). Peraturan lainnya yang khusus mengatur tentang akad dalam kegiatan usaha berdasarkan prinsip syariah adalah Peraturan Bank Indonesia Nomor 10/16/PBI/2008 tentang Perubahan atas Peraturan Bank Indonesia Nomor 9/19/PBI/2007 tentang Pelaksanaan Prinsip Syariah dalam Kegiatan Penghimpunan Dana dan Penyaluran Dana serta Pelayanan Jasa Bank Syariah. Peraturan lain yang memberikan dasar bagi beroperasionalnya Perbankan Syariah adalah Undang-undang Nomor 50 Tahun 2009 tentang perubahan kedua atas Undang-undang Nomor 7 Tahun 1989 tentang Peradilan Agama. Di dalam undang-undang tentang peradilan agama terdapat pengertian ekonomi syariah, di dalamnya terdapat perbankan syariah dan adanya kompetensi absolut Peradilan Agama dalam menyelesaikan sengketa ekonomi syariah. Didasarkan pada Pasal 41 huruf i Undang-undang Nomor 3 Tahun 2006 tentang Peradilan Agama sebagaimana telah diubah dengan UU No. 50 Th. 2009 tentang Perubahan Kedua atas UU No. 3 Th. 2006 tentang Peradilan Agama.

"Kegiatan muamalah yang terkait dengan aspek ekonomi meliputi kegiatan untuk meningkatkan kesejahteraan dan kualitas hidup, seperti: jual beli, simpan pinjam, utang piutang, usaha bersama dan sebagainya". Hal ini sebagaimana pendapat Perwataatmadja dan Antonio.. Di dalam muamalah dikenal dengan Aqad. Aqad merupakan bagian dari tasharruf. Tasharruf adalah segala yang keluar dari seorang manusia dengan kehendaknya dan syara' menetapkan beberapa hak.

Suhendi membagi Tasharruf menjadi dua, yaitu "tasharruf fi'li dan tasharruf qauli. Tasharruf fi'li adalah usaha yang dilakukan manusia dengan tenaga dan badannya selain dari lidah, seperti memanfaatkan tanah yang tandus, menerima barang dalam jual-beli, merusak benda orang lain. Tasharruf qauli ialah tasharruf yang keluar dari lidah manusia yang dibagi menjadi dua, yaitu aqdi dan bukan aqdi. Tasharruf qauli aqdi adalah sesuatu yang dibentuk dari ucapan kedua belah pihak yang saling bertalian, seperti jual-beli, sewamenyewa dan perkongsian. Tasharruf qauli bukan aqdi ada dua macam, yaitu: (a) Merupakan pernyataan pengadaan dua hak atau mencabut suatu hak, seperti wakas, thalak dan memerdekakan; (b) Tidak menyatakan suatu kehendak, tetapi dia mewujudkan tuntutan-tuntutan hak, seperti gugatan, iqrar, sumpah untuk menolak gugatan"(Suhendi, 2002).

Pembiayaan bermasalah dalam praktik banyak terjadi dan memerlukan solusi. Salah satu pengertian pembiayaan bermasalah adalah salah satu dari lima masalah besar yang dihadapi perbankan nasional. Pengertian pembiayaan bermasalah menurut 
pengertian bank adalah "pembiayaan yang berada dalam klasifikasi diragukan dan macet (non performing loans)". Dalam hal terdapat pembiayaan bermasalah, bank menjaga likuiditasnya dengan berusaha mengupayakan penyelesaian permasalahan yang dihadapinya.

Beberapa asas yang harus diperhatikan dalam penyelesaian sengketa antara lain adalah asas kehati-hatian di dalam mengelola proses secara syariah. Harapan dengan penerapan asas kehati-hatian akan memberikan kepastian dan mencegah adanya permasalahan di dalam pelaksanaan akad. Hal ini sesuai dengan pendapat Shaykh Yusuf Talal De Lorenzo yang menyebutkan bahwa: "careful management of the shariah process will almost certainly help prevent this risk from becoming a problem" (Lorenzo, D. and Talal, 2007). Pendapat Shaykh Yusuf De Lorenzo sesuai dengan Asas Pacta Sunt Servanda yang berarti bahwa akad para pihak yang dibuat secara sah mengikat para pihak sebagai undang-undang.

Dalam pasal penyelesaian perselisihan akad melalui perbankan syariah terdapat tahapan penyelesaian: Pertama, diupayakan penyelesaian secara musyawarah dan mufakat. Kedua, diupayakan penyelesaian melalui BASYARNAS. Selain penyelesaian melalui musyawarah dan Arbitrase Syariah maka ada alternatif penyelesaian sengketa melalui mediasi. "Mediasi merupakan proses pemecahan masalah di mana pihak luar yang tidak memihak (impartial) dan netral bekerja dengan pihak yang bersengketa untuk membantu memperoleh kesepakatan perjanjian yang memuaskan". Berdasarkan pengertian tersebut maka mediator berbeda dengan hakim atau arbiter, mediator tidak mempunyai wewenang untuk memutuskan sengketa antara para pihak namun dalam hal ini para pihak menguasakan kepada mediator untuk membantu mereka menyelesaikan persoalan-persoalan.

Margono berpendapat dengan mengutip dari pendapat Kovact: bahwa "mediasi berarti facilitatied negotiation, it process by which a neutral third party, the mediator, assist disputing parties in reaching a muttually satisfaction solution". (Margono, 2004). Berdasarkan rumusan dari Margono, dapat ditarik beberapa hal penting yaitu sebagai berikut: (a) Mediasi ialah suatu proses penyelesaian sengketa berdasarkan perundingan; (b) Mediator terlibat dan diterima oleh para pihak yang bersengketa di dalam perundingan; (c) Mediator bertugas membantu para pihak yang bersengketa untuk mencari penyelesaian; (d) Mediator tidak mempunyai kewenangan membuat keputusan selama perundingan berlangsung; (e) Tujuan mediasi adalah untuk mencapai atau menghasilkan kesepakatan yang dapat diterima pihak-pihak yang bersengketa guna mengakhiri sengketa.

Thalis Noor $\mathrm{C}$ mengutip pendapat Bambang Sutiyoso tentang mediasi sebagai "mekanisme penyelesaian dengan pihak ketiga (mediator) yang tidak memihak (impartial) yang turut aktif memberikan bimbingan atau arahan guna mencapai penyelesaian, namun ia tidak berfungsi sebagai hakim yang berwenang mengambil keputusan. Inisiatif penyelesaian tetap berada pada tangan para pihak yang bersengketa". Dengan demikian hasil penyelesaiannya bersifat kompromi. "Pendapat Sutiyoso ini menurut pendapat Thalis sejalan dengan pendapat Loveinheim", yang menyebutkan bahwa "Mediation is a process in which two or more people involved in a dispute come together, to try to work out a solution to their problem with the help of a neutral third person, called the Mediator" (Thalis, 2011).

Dalam perkembangannya, penyelesaian sengketa perbankan syariah melalui OJK dan Lembaga Alternatif Penyelesaian Sengketa (LAPS) ada yang terangkai dengan hukum acara perdata di pengadilan negeri maupun pengadilan agama. Penyelesaian sengketa melalui OJK didasarkan pada: (a) Undang-undang Nomor 21 Tahun 2008 tentang Perbankan Syariah; (b) Undangundang Nomor 21 Tahun 2011 tentang Otoritas Jasa Keuangan; (c) POJK No. 1 Th. 2013 tentang Perlindungan Konsumen 
Sektor Jasa Keuangan dan POJK No. 1 Th. 2014 tentang Lembaga Alternatif Jasa Keuangan di Sektor Jasa Keuangan; (d) Surat Edaran Otoritas Jasa Keuangan Nomor 54 SEOJK.07/2016 tentang Monitoring Lembaga Alternatif Penyelesaian Sengketa di Sektor Jasa Keuangan; (e) Keputusan Nomor KEP-01/D.07/2016 tanggal 21 Januari 2016 tentang Daftar Lembaga Alternatif Penyelesaian Sengketa Di Sektor Jasa Keuangan; (f) Standar Operating Prosedur (SOP) sebagai acuan dalam penyelesaian sengketa di dasarkan pada SE OJK Nomor 2/SEOJK.07/2014 tentang Pelayanan dan Penyelesaian Pengaduan Konsumen pada Pelaku Jasa Keuangan sebagaimana telah diuraikan pada bagian pendahuluan di atas.

Hubungan hukum antara bank dan nasabah timbul karena adanya pembiayaan dan didasarkan pada Akad Pembiayaan. Penggunaan Akad Pembiayaan dilakukan berdasarkan kepatuhan pada Hukum Islam dan Fiqh Muamalah. Hal ini sesuai dengan pendapat Ahmad Ibrahim yang menyebutkan: "Banking and Financial operation undertaken by Muslims will have to be conducted in compliance with the shariah laws and the Fiqh al-Muamalah. The modern banking and financial system has come into being to meet the human needs for financing from the capital belonging to others, other than one's self and these take the form of either equity financing or debt financing" (Ibrahim, 1997).

Permasalahan yang dihadapi perbankan nasional, salah satunya adalah pembiayaan bermasalah. Pengertian pembiayaan bermasalah menurut pengertian bank adalah "pembiayaan yang berada dalam klasifikasi diragukan dan macet (non performing loans)". Dalam hal terdapat pembiayaan bermasalah, bank menjaga likuiditasnya dengan berusaha mengupayakan penyelesaian permasalahan yang dihadapinya. Di samping itu prinsip kehatihatian di dalam mengelola proses secara syariah akan memberikan kepastian dan mencegah adanya permasalahan di dalam pelaksanaan akad. Penerapan prinsip kehatihatian sebagaimana telah diuraikan oleh Gemala Dewi, Sutan Remy Syahdeini, Ridwan Khaerandy diiringi dengan penerapan prinsip syariah. Prinsip kehatihatian dan prinsip syariah diterapkan oleh bank dalam menjalankan fungsinya sebagai agent of trust sebagaimana dikemukakan oleh Irfan Lubis. Pendapat demikian juga sesuai dengan pendapat Shaykh Yusuf Talal De Lorenzo yang menyebutkan bahwa: "careful management of the sharia process will almost certainly help prevent this risk from becoming a problem" (Lorenzo, D. and Talal, 2007). Berdasarkan asas dalam akad maka diterapkan Asas Pacta Sunt Servanda yang berarti bahwa akad para pihak yang dibuat secara sah mengikat para pihak sebagai undang-undang.

Kewenangan OJK dalam menyelesaikan sengketa perbankan syariah didasarkan pada Pasal 29 huruf c Undang-undang Nomor 21 Tahun 2011 tentang Otoritas Jasa Keuangan (selanjutnya ditulis UU OJK). Hal tersebut dilakukan oleh OJK dalam rangka memberikan perlindungan bagi konsumen dan masyarakat sebagaimana diamanahkan oleh Pasal 28 UU OJK.

Menurut Soerjono Soekanto, "pengertian efektifitas hukum dalam tindakan atau realita hukum dapat diketahui apabila seseorang menyatakan bahwa suatu kaidah hukum berhasil atau gagal mencapai tujuannya, oleh karena itu biasanya diketahui apakah pengaruhnya berhasil mengatur sikap tindak atau perilaku tertentu sehingga sesuai dengan tujuannya atau tidak. Dalam masyarakat Indonesia, efektifitas hukum berarti daya kerja hukum dalam mengatur dan memaksa warga masyarakat untuk taat terhadap hukum. Efektifitas hukum berarti mengkaji kaidah hukum yang harus memenuhi syarat secara yuridis, sosiologis dan filosofis" (Soekanto, 2008).

Efektifitas hukum terlebih dahulu harus dapat diukur dengan melihat sejauh mana aturan hukum itu dipatuhi dan ditaati atau tidak ditaati. Jika suatu aturan hukum itu ditaati oleh sebagian masyarakat maka 
aturan hukum tersebut dapat dikatakan sudah efektif. Namun demikian, sekalipun ketaatan terhadap hukum itu sudah efektif tetapi masih dipertanyakan maka bisa dikatakan masih jauh derajat keefektifitasannya.

Jika ketaatan sebagian besar masyarakat terhadap suatu aturan hukum karena hanya kepentingan yang bersifat compliance atau hanya takut sanksi maka derajat keefektifan hukum tersebut masih sangat rendah karena harus dilakukan pengawasan terus menerus. Berbeda jika ketaatan karena berdasarkan pada kepentingan yang bersifat internalization yaitu ketaatan karena aturan hukum tersebut benar-benar cocok dengan nilai intrinsik yang dianutnya maka derajat ketaatannya lebih tinggi.

Berdasarkan Teori Efektifitas dari Soerjono Soekanto sebagaimana telah disebutkan di atas, "efektif atau tidaknya suatu hukum ditentukan oleh 5 (lima) faktor, yaitu faktor hukumnya sendiri (undangundang), faktor penegak hukum, yakni pihak-pihak yang membentuk maupun menerapkan hukum, faktor sarana atau fasilitas yang mendukung penegakan hukum, faktor masyarakat dan faktor kebudayaan".

Beberapa teori yang telah disebutkan di atas jika diterapkan pada fakta dari hasil penelitian di lapangan, khususnya di OJK Jawa Tengah dan DIY bahwa penyelesaian sengketa perbankan syariah yang dilakukan berhasil selesai $100 \%$. Hal ini berarti bahwa seluruh proses pengaduan nasabah yang masuk dan diselesaikan melalui OJK telah berhasil diselesaikan. Jika dikaji berdasarkan teori efektifitas penegakan hukum dari Soerjono Soekanto yang menyebutkan bahwa faktor-faktor penegakan hukum ada lima. Faktor pertama, adalah faktor hukumnya sendiri dalam hal ini sudah ada UU No. 21 Th 2008, UU No. 21 Th. 2011, POJK No. 1 Th. 2013, POJK No. 1 Th. 2014, SEOJK No. 54 Th. 2016 dan SEOJK No. 2 Th. 2014.

Faktor kedua adalah penegak hukumnya, dalam hal ini fasilitasi dilakukan oleh personil di bidang edukasi dan perlindungan konsumen di OJK. Jika kesepakatan tidak terwujud maka kewenangan menyelesaikan sengketa dilanjutkan atau diserahkan ke Lembaga Alternatif Penyelesaian Sengketa (LAPS). Berdasarkan KEP No. 01 Th. 2016 sudah ada 6 (enam) lembaga alternatif penyelesaian sengketa yang melaksanakan model mediasi, arbitrase dan adjudikasi. 6 (enam) lembaga tersebut adalah: a. Badan Mediasi dan Arbitrase Asuransi Indonesia (BMAI, b. Badan Arbitrase Pasar Modal Indonesia (BAPMI), c. Lembaga Alternatif Penyelesaian Perbankan Syaraiah Indonesia (LAPSI), d. Badan Arbitrase dan Mediasi Perusahaan Penjaminan Indonesia (BAPMI), e. Badan Mediasi Pembiayaan dan Pegadaian Indonesia (BMPPI). Dalam hal ini di masing-masing LAPS terdapat personil yang menjadi mediator, arbiter. Jika penyelesaian sengketa melalui mediator dan arbiter juga belum dapat menyelesaikan sengeta antar nasabah dengan bank syariah. Salah satu pihak dapat memilih model adjudikasi ke peradilan agama.

Faktor ketiga, sarana dan prasarana yang dimiliki oleh OJK sangat memberikan dukungan dalam proses penyelesaian sengketa perbankan syariah. Dalam praktiknya di OJK Semarang juga melayani proses fasilitasi dengan cara fasilitator memberikan tempat dan fasilitas dalam penyelesaian permasalahan. Fakta ini dapat memperkuat dalam memberikan kemudahan kepada masyarakat dalam penyelesaian sengketa perbankan syariah.

Faktor keempat, adalah masyarakat, dalam hal ini pemahaman dan penerimaan masyarakat terhadap keberadaan OJK dalam memberikan perlindungan kepada konsumen dan adanya kemauan untuk memahami perkembangan baru tentang ruang lingkup dari OJK dalam menyelesaikan sengketa. Masyarakat beranggapan bahwa penyelesaian sengketa melalui OJK oleh sebagian masyarakat belum efektif karena ada sebagian masyarakat yang pernah ditolak penyelesaian melalui OJK. Dalam hal ini terjadi karena belum adanya pemahaman masyarakat tentang ruang 
lingkup dan alasan penolakan dalam penyelesaian permasalahan,

Faktor kelima, budaya masyarakat, dalam penyelesaian sengketa perbankan syariah memerlukan dukungan dari budaya masyarakat setempat. Budaya masyarakat sangat mempengaruhi berhasil atau tidaknya proses penyelesaian sengketa yang dilakukan di OJK. Seperti budaya damai yang terjadi di masyarakat, jika hal ini terdapat pada diri masing-masing pihak yang akan menyelesaikan sengketa, yaitu dari pihak konsumen dan lembaga jasa keuangan maka penyelesaian sengketa akan berjalan secara efektif.

\section{Implementasi Model Penyelesaian Sengketa yang Diterapkan}

Implementasi penyelesaian sengketa di OJK dilakukan berdasarkan beberapa peraturan sebagaiman diuraikan di atas. Selain itu juga didasarkan pada teori penyelesaian dan teori kewenangan. Berdasarkan teori penyelesaian sengketa menurut Salim bahwa OJK berwenang dalam menyelesaiakan sengketa perbankan syariah (Salim, 2013). "Teori penyelesaian sengketa merupakan teori yang mengkaji dan menganalisis tentang kategori atau penggolongan sengketa atau pertentangan yang timbul dalam masyarakat, faktor penyebab terjadinya sengketa dan cara-cara atau strategi yang digunakan untuk mengakhiri sengketa tersebut". Sedangka Teori Kewenangan menurut Salim HS adalah "teori yang mengkaji dan menganalisis tentang kekuasaan dari organ pemerintah untuk melakukan kewenangannya, baik dalam lapangan hukum publik maupun hukum privat"(Salim, 2013). Adapun unsur-unsur yang tercantum dalam teori kewenangan meliputi: "adanya kekuasaan, adanya organ pemerintah dan sifat hubungan hukumnya".

Pendapat lain dikemukakan oleh Neni Sri Imaniyati yang menyebutkan bahwa Peraturan OJK menetapkan penyelesaian sengketa dapat dilaksanakan di luar pengadilan atau melalui pengadilan (Imaniyati, 2013). Berdasarkan teori penyelesaian sengketa dan teori kewenangan tersebut maka implementasi penyelesaian sengketa di OJK dilakukan dengan model fasilitasi yang berbeda dengan mediasi. Untuk penyelesaian sengketa dengan model mediasi dilakukan oleh LAPS yang saat ini telah beroperasi yang didasarkan pada Keputusan Nomor KEP-01/D.07/2016.

\section{Simpulan dan Saran}

Berasarkan uraian pada pembahasan di atas maka penyelesaian sengketa perbankan syariah melalui OJK berjalan secara efektif yang didasarkan pada Teori Efektivitas dari Soerjono Soekanto, Teori Kekuasaan dan Teori Kewenangan dari Salim HS. Efektifitas penyelesaian sengketa ini juga dilakukan dengan penerapan prinsip syariah dan keahati-hatian serta fungsi bank syariah sebagai agent of trust dari masyarakat yang diperkuat oleh keberadaan OJK. Efektivitas penyelesaian sengketa dapat dilihat dengan capaian seluruh pengaduan yang diterima oleh OJK melalui bagian edukasi dan perlindungan konsumen di OJK DIY maupun Jawa Tengah dapat diselesaikan $100 \%$. Penyelesaian pengaduan dilakukan sesuai dengan jangka waktu yaitu 20 (dua puluh) hari kerja dengan perpanjangan hingga 30 (tiga) puluh hari kerja. OJK dalam praktiknya telah menerapkan model penyelesaian sengketa dengan teknik fasilitasi dengan melakukan klarifikasi kepada para pihak.

Dalam hal penyelesaian sengketa tidak terwujud kesepakatan di antara kedua belah pihak dalam jangka waktu 20-30 hari kerja dengan kemungkinan adanya perpanjangan jika ada situasi dan kondisi tertentu sesuai peraturan yang ada maka para pihak dapat menyelesaikan melalui Lembaga Alternatif Penyelesaian Sengketa (LAPS) dengan pilihan mediasi, arbitrase maupun adjudikasi. Seyogyanya model fasilitasi dengan cara klarifikasi ini disosialisasikan lebih luas kepada masyarakat baik kepada pengguna jasa lembaga keuangan syariah, PUJK maupun nasabah. Edukasi kepada masyarakat khusus tentang model fasilitasi dengan klarifikasi dapat menjadi raw model 
penyelesaian sengketa alternatif di luar penyelesaian sengketa perbankan syariah. Kekuatan penyelesaian sengketa melalui fasilitasi ini karena fasilitator tidak mempertemukan para pihak dalam suatu forum. Hal ini dilakukan untuk antisipasi adanya perbedaan karakter antara nasabah dengan PUJK. Adapun kelemahan dari fasilitasi adalah jika salah satu pihak tidak mempunyai komitmen dan beritikad tidak baik (beritikad buruk). Peluang mekanisme fasilitasi adalah kesempatan proses penyelesaian sengketa secara sederhana, cepat dan tanpa biaya bagi para pihak, sedangkan tantangan mekanisme fasilitasi adalah diperlukan kedisiplinan, kejujuran dan komitmen yang tinggi dari para pihak serta diperlukan kompetensi dan profesionalisme dari fasilitator.

\section{E. Ucapan Terima Kasih}

Para penulis ingin menyampaikan ucapan terima kasih yang terdalam kepada semua Pimpinan di UMY dan LP3M UMY atas kesempatan dan pendanaan yang diberikan kepada penulis dalam melakukan penelitian. Ucapan terima kasih juga diberikan kepada Pimpinan Fakultas Hukum UMY atas dukungan dalam pengurusan ijin penelitian dan dukungan dari tenaga kependidikan untuk dukungan yang diberikan dalam rangkaian penelitian dan upaya dalam mempublikasikan artikel ini.

\section{DAFTAR PUSTAKA}

Dewi, G. (2006). Aspek-aspek Hukum dalam Perbankan dan Perasuransian Syariah di Indonesia. Jakarta: Kencana.

Ibrahim, A. (1997). Legal Framework of Islamic Banking. Jurnal UndangUndang, IKIM Law Journal, 1(1), 6.

Imaniyati, N. . (2013). Metoda dan Bentuk Penyelesaian Sengketa Pasca Lahirnya Putusan Mahkamah Konstitusi No, 93/PUU-X/2012 dan Peraturan Otoritas Jasa Keuangan No. 1 Th. 2013. Jurnal Scientica, 1(1), 74.
Khairandy, R. (2004). Iktikad Baik dalam Kebebasan Berkontrak. Jakarta: Program Pasca Sarjana Fakultas Hukum Universitas Indonesia.

Lorenzo, D. and Talal, S. . (2007). Shari'ah Compliance Risk. Chicago Journal of International Law, 7(2).

Lubis, I. (2010). Band dan Lembaga Keuangan Lain. Medan: USU Press.

Margono, S. (2004). ADR \& Arbitrase (Proses Pelembagaan dan Aspek Hukum). Bogor: Ghalia Indonesia.

Maulin, M. dan Mulyaningsih, H. . (2014). Judicial Review Against The financial Agreement in The Islamic Bank in Indonesia Review of Act No. 30 of 2004 Concerning Notary. In International Proceeding of Economics Development and Research Volume 73 (p. 19).

Radliyah, N. and Musjtari, D. N. (2017). The Reposition of Mediation Process in Islamic Economic Dispute Resolution Through Religious Court After Perma No. 1 of 2016. In Proceeding International Conference on Law and Society. Yogyakarta: LP3M \& Faculty of Law, Universitas Muhammadiyah Yogyakarta.

Salim, H.; N. (2013). Penerapan Teori Hukum pada Penelitian Tesis dan Disertasi. Jakarta: Raja Grafindo Persada.

Sawitri, A. . (2016). Mediasi Perbankan Sebagai Alternatif Penyelesaian Sengketa Bank dan Nasabah melalui Otoritas Jasa Keuangan. Surakarta: . Surakarta: Fakultas Hukum Universitas Slamet Riyadi.

Simarmata, R. (2007). Socio-Legal Studies dan Gerakan Pembaharauan Hukum dalam Digest Law. Society and Development, 1 .

Soekanto, S. (2008). Faktor-Faktor yang Mempengaruhi Penegakan Hukum. 
Jakarta: Raja Grafindo Persada.

Suhendi, H. (2002). Fiqh Muamalah. Jakarta: Raja Grafindo Persada.

Syahdeini, S. . (1999). Perbankan Islam dan Kedudukannya dalam Tata Hukum Perbankan Indonesia. Jakarta: Pustaka Utama Grafiti.
Thalis, N. C. (2011). Penyelesaian Sengketa Perbankan Syariah. Jurnal Ekonomi Syariah Indonesia, 1(2).

Zaini, A. (2018). Mediasi sebagai Salah Satu Bentuk Alternatif Penyelesaian Sengketa. Al Qiatash, Jurnal Hukum Dan Politik, 9(2), 81. 